\title{
The Paradox of Inclusion/Exclusion of Islamist Parties in Tunisia and Jordan after the Arab Uprisings: A Comparative Study
}

\author{
NUR KÖPRÜLÜ \\ Near East University, Turkish Republic of Northern Cyprus \\ ORCID No: 0000-0002-6978-1891
}

\begin{abstract}
The public protests that engulfed most Arab regimes in 2011 have since opened a Pandora's Box of democratization processes in the MENA region. One of the upshots of the popular uprisings has been the empowerment of the key opposition group in the region, i.e. mainly Islamist actors. Despite the electoral victories of Islamist political parties after decades of political exclusion, the Islamist movement and its agenda in the post-Arab Spring era have followed different trajectories in various countries around the region. This article aims to explore the divergent trajectories of two countries in the region, namely the inclusion of Islamists in the case of Tunisia and their exclusion in the case of Jordan. As a corollary, the divergent domestic and regional contexts shaping the politics of Islamist parties will be explored.
\end{abstract}

Keywords: Middle East, Tunisia, Jordan, Islamism, Democratization, Party Politics

Insight Turkey 2020

Vol. 22 / No. 1 / pp. 211-235 
T he Islamist movement has undergone sporadic transformation since the onset of the 2011 Arab uprisings. The main questions that have arisen are whether the public protests will lead to democratic transition and what roles the opposition parties and Islamist actors will take. One of the key outcomes of the series of protests has been the electoral victory of Islamists, as in cases like Tunisia and Egypt. Ikhwan-affiliated groups have been described as the foremost champions of the uprisings despite their late involvement in the 2011 rallies and Islamist actors have undergone a transformation hitherto.

With the aim of exploring in greater depth the role of Islamist parties and how they were treated by regimes after the Arab Spring, two countries from the Maghreb and Mashreq regions -one republican and one monarchical- have been selected as case studies. The main reason for the case-selection in this article is derived from the fact that Islamist political parties -who represent the most organized and strongly ideological forces in the region since the 1970sdidn't come to power in the entire Arab world after the large-scale public protests, as some had argued. ${ }^{1}$ In line with its aims, this article also emphasizes the variation in the trajectories of state and nation formation in both Maghreb and Mashreq countries in order to illustrate the repercussions of regional dynamics shaping both domestic politics and internal schisms in the Arab Middle East. In this regard, the examples of Tunisia and Jordan and the respective regimes' responses in building relations with the old Islamist actors in both countries, mark the fact that Arab states around the Middle East and North Africa (MENA) region are not monolithic, and there is no single coherent Arab world. In addition, despite its permeable and embedded history, the Islamist movement (precisely Ikhwan) in the region today displays different trajectories in each country in the post-2011 era regardless of their similar ideological background and shared past. Although the primary groups of Islamists in Tunisia and Jordan have their roots from the Muslim Brotherhood society (Ikhwan) and both represent non-violent/moderate Islamist activism in the region, ${ }^{2}$ they have been inversely responded to by their regimes. For instance, in Tunisia, the 'excluded' Islamist actor, al-Nahda, has become an indispensable part of the democratic transition, while Jordan's Ikhwan -despite its longtime close relations with the monarchy- has been upended since the uprisings. Variation in regimes' responses to the rise of Islamist parties around the region is, thus, context dependent. The nature of the variation is, in fact, three-fold. First of all, the demands of the protesters articulated during the public rallies in several countries were diverse; the cases of Tunisia and Jordan, in this sense, should not be taken as typical. Secondly, the role and nature of Islamist parties has to be analyzed alongside the degree/level of democratization in each case study. In other words, each country has its own indigenous/national context and dynamics, just as each has followed its own trajectory of state-formation, as well as divergent histories of political parties and social mobilization. Lastly, each country's interpretation of 'Islam' as a religion was re-constructed in con- 
cert with state identity, being repressed in Tunisia by the regime but embraced by the Hashemites in Jordan, until the 2011 uprisings.

Thus, the Arab uprisings have revealed that there is no coherence in how Islamist parties have responded to and been treated since the protests; each country has employed its own methods in containing both Islamists and popular unrest. In this regard, the post-Arab Spring ${ }^{3}$ era has highlighted the diverse trajectories of state-formation in the region, as well as the particularities of state-society relations and the democratization efforts of regimes in (re)constructing each country's 'spring.' Despite differing trajectories of identity and state-formation in both countries, the article will then highlight the argument that the formation of Islamist politics has filled the ideological gap left by Arab nationalism in the region; and for that purpose, it is still valid and is not yet outdated in the light of the Arab protests.

\section{Islamist Parties and Post-Islamism Revisited after the Uprisings}

The series of public protests across the MENA region that erupted first in 2010 and became known as the Arab uprisings has brought Political Islam and Islamist parties back on to the region's agenda. ${ }^{4}$ Although Islamists were late to join the demonstrators calling for economic and political reforms, some have argued that Islamists hijacked the Arab Spring. ${ }^{5}$ According to Katerina Dalacoura, "None of the 2011 uprisings in the Arab Middle East was led by Islamist movements or had a predominantly Islamist agenda."6 In addition, in the case of Egypt, the Kefaya (Enough) movement, the 'April 6' youth group and 'We Are All Khaled Said' initiative, as well as the trade unions; likewise in the case of Tunisia workers under the umbrella of the key trade union of the country UGTT and the protestors from secular, centrist, liberal, and middle class groups all gathered at public rallies during 2011. However, the electoral victories of the Tunisian al-Nahda and the Egyptian Muslim Brotherhood -who received 37 percent and 37.5 percent of votes respectively in the first post-2011 parliamentary elections- have led to a re-visitation of the rhetoric of post-Islamism. Both cases demonstrate that Islamist parties and Islamist politics are still salient. Asef Bayat and Olivier Roy, who put forward the notion of post-Islamism, have argued that "Islamism has gradually lost its credibility and that in its place we find a new discourse of exploration and contention over the role of Islam in politics." The rationale behind this argument is closely tied with the changing 
The notion of post-Islamism may not be sufficient to define and contextualize the role of al-Nahda and other Islamist parties, and their compliance with democratic values and embracement of the liberal market economy in the post-uprisings era political discourses of Islamist movements, such as Egypt's Ikhwan and Tunisia's al-Nahda, which as political parties "significantly departed from the original Islamist project of establishing an Islamic state" and prioritize politics over religion. ${ }^{8}$ For instance, Bayat argues that "In contemporary Iran, post-Islamism is expressed in the idea of fusion between Islam (as a personalized faith) and individual freedom and choice; and post-Islamism is associated with the values of democracy and aspects of modernity ... Yet, there is also a strong quest for an independent modernity." For Bayat, "We may be witnessing the coming of a post-Islamist Middle East, in which the prevailing popular movements assume a post-national, post-ideological, civil, and democratic character." ${ }^{\prime 0}$

A contending argument to Bayat and Roy was put forward by Cavatorta and Merone, who claim that "To a certain extent, it is rather sterile to once again talk about the failure or the end of Islamism." ${ }^{11}$ In the post-1990 era, the "category of Islamism still holds considerable importance" for them. ${ }^{12}$ Thus, the rhetoric of post-Islamism, which has been regarded as an ideological project alternative to liberal-democracy, began to be challenged after the Arab uprisings for two main reasons. Foremost, the ideological evolution and transformation of Islamist parties in the post-2011 era -like the cases of al-Nahda and Ikhwan - has to be taken on board. ${ }^{13}$ As al-Anani suggests, "The Arab Spring has ended the old image of Islamists as 'victims' of autocratic regimes ... Islamists will try to preclude the reproduction of the old authoritarian regimes." 14 Nevertheless, in most cases, Islamists have been seen as the main beneficiaries of the public protests, and in the eight years since, their integration or inclusion among the emergent factions has been endemic.

The second point that arose after the 2011 riots was the necessity to reassess the role of Islamism in processes of democratization in the MENA region. At the beginning of the protests, it seemed that Islamists would come to power with a linear increase in the trend towards democratization. The Muslim Brotherhood Society which is one of the oldest and most organized Islamist groups in the MENA region has been considered as one of the fundamental actors of the uprisings. ${ }^{15}$ One of the key debates at this point was whether or not Islamists' exclusion from the system culminates in marginalization of these groups. The exclusion from the political system as it was in the very case of Tunisia's al-Nahda did not, however, result in radicalization of Islamist politics as some argued. In the aftermath of the public riots, the moderate or centrist Is- 
lamists - which were primarily the Ikhwan-affiliated groups- have shown their full commitments with a variety of discourses and practices to work within the boundaries of the political arena, if not with the ruling elites. In this regard, Jordan's Islamic Action Front (IAF), the Moroccan Justice and Development Party (JDP) and Egypt's Freedom and Justice Party (FJP-despite its short-lived rule until its overthrow in 2013 through a coup détat), have all depicted their compliance with existing liberal-democratic rules and willingness to embrace issues on human rights and gender equality in the public sphere.

Thus, moderate Islamism in the MENA region is more or less associated with the Muslim Brotherhood Society due to its traditional non-violent approach. As Robin Wright indicated, Tunisia's al-Nahda and Morocco's JDP represent two key branches of Ikhwan that mobilized as moderate movements, labeling them 'neo-Islamists.' ${ }^{16}$ For Wright, neo-Islamists can be described as "progressive, pragmatic and striving for sharia's goals rather than its literal implementation." ${ }^{17}$

Thus, the notion of post-Islamism -which was put forward in response to the changes in Islamist politics and agenda after the 1990s- may not be sufficient to define and contextualize the role of al-Nahda and other Islamist parties, and their compliance with democratic values and embracement of the liberal market economy in the post-uprisings era. Islamist parties' realignment with liberal-democratic procedures and the implementation of personal status legislation does not mean that their Islamist character has eroded. This ideological evolution has rather repositioned them to act as conservative parties within the indigenous/national and regional contexts they are embedded in. For instance, the case of Tunisia's ongoing democratic transition -the most progressive in the region- discloses the significance of its national context and state-formation process in the transformation of Islamist politics. This has produced a secular-Islamist schism in the country, unlike the case of Jordan, which will also be explored.

This article aims to illustrate that al-Nahda in Tunisia has been successfully integrated into the political system, while in Jordan Islamists have come to be seen as a threat since the Arab spring. These two cases will demonstrate that Islamist politics and activism remain endemic and salient, while also helping to reveal the variety of forms it has taken around the region.

\section{The Tunisian Spring: From Authoritarianism towards Democratic Transition}

Tunisia became the homeland of the Arab public riots on December 17, 2010, after the self-immolation of Mohammad Bouazizi. Internal unrest had been aroused due to increased unemployment and corruption, then by early 2011 
The case of al-Nahda illustrated after the Arab riots that the traditional view of Orientalists, which sees Islam as the antithesis of liberal-democracy, is controversial given the acceptance of Islamist actors in the post-Arab upheavals era of universal liberal values and inclusionary attitudes had transformed into large-scale public demonstrations calling for the overthrow of President Zine al-Abidin Ben Ali, who had been ruling the country since 1987 . Since then Tunisia has moved into an ambidextrous phase, shifting from authoritarianism towards democratization. Today, the democratic transition in Tunisia represents the most successful outcome of the Arab uprisings -which can be compared to Egypt's constitutional drafting process for reference. The Guardian suggested that the "longer drafting process by [the] elected assembly helped create one of [the] Arab world's most progressive constitutions." ${ }^{18}$ In this regard, Tunisians became in time more inclusionary as they adopted liberal-democratic values, fostering reconciliation among the various actors involved in public protests.

Tunisia is a regional example of an Arab republican authoritarian and populist regime aiming to acquire its legitimacy from anti-imperialist and Arab nationalist loyalties. ${ }^{19}$ So, the political regime primarily established by former President Habib Bourguiba was pioneered through a secular identity that excluded Islamist actors like al-Nahda. As a result, this exclusion came to underpin the ideological trajectory of Tunisia's Islamists and has promoted intra-Islamist debate within the Mouvement de la Tendence Islamique (MIT) -today's alNahda (Renaissance Party). For Cavatorta and Merone,

The popular gains that the Islamist movement had made throughout the 1980s after their first rupture with their jamaa past had forced Tunisian secular parties to come to terms with the popularity of doing politics through religion. This turned them against any expression of political religiosity, whether moderate or radical, because this would fundamentally alter the secular nature of the state. ${ }^{20}$

Between the late 1970s and early 1980s, the movement evolved in three different directions: liberal, radical, and those affiliated with Rachid al-Ghannouchi, who formed MIT (today's al-Nahda). This intra-Islamist debate shifted the party towards a moderate position, preventing it from being marginalized by the incumbent rule.

With the first parliamentary elections held in the post-2011 era, a governmental coalition was established between the majority party, al-Nahda, and the Congress for the Republic (CPR) and the Democratic Forum for Labor and 


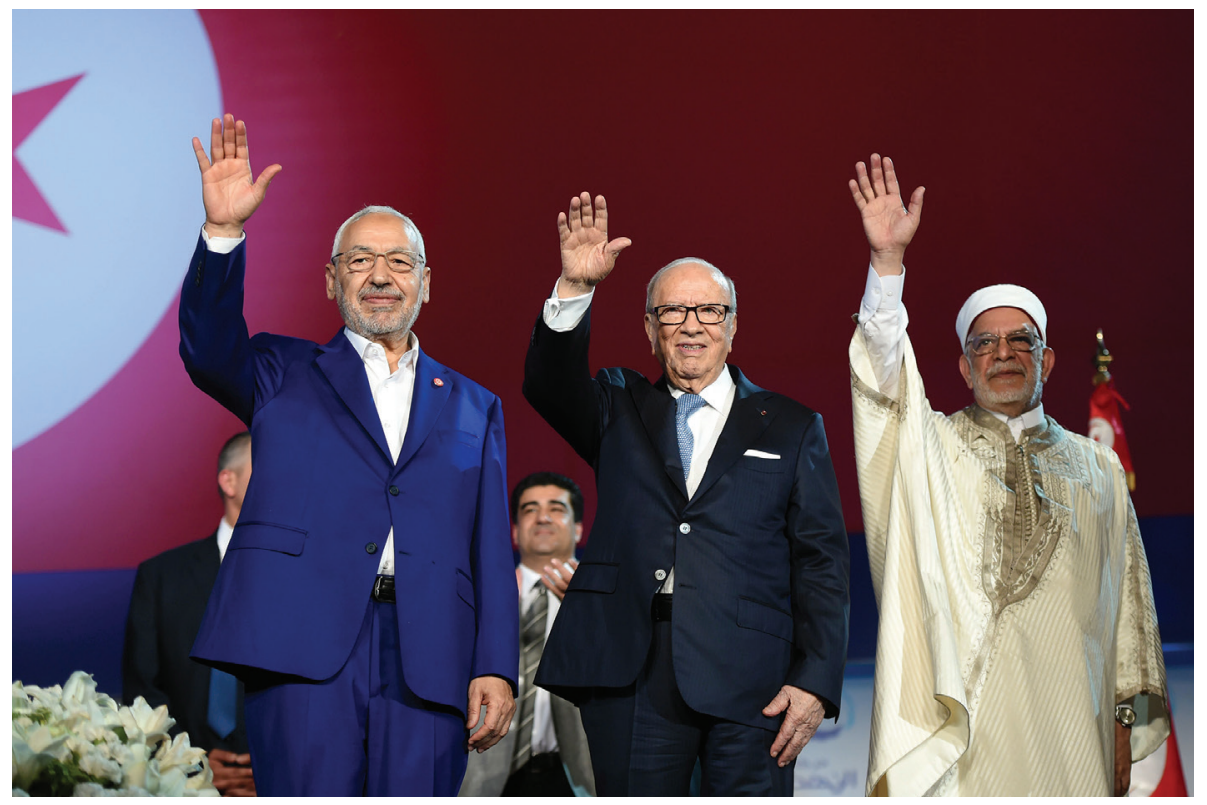

Tunisian President es-Sebsi (C), al-Nahda Leader Ghannouchi (L), and al-Nahda Party Vice-president Mourou (R) wave to the crowd on May 20, 2016 at the opening of $a$ Nahda's three-day congress in Tunis. FETHI BELAID / AFP / Getty Images

Liberties (called as Ettakatol) representing secular-centrist and leftist ideologies. The elections, then, paved the way for 217 members of parliament to draft a new constitution. The subsequent parliamentary elections were held in October 2014, and a governmental coalition was formed consisting of al-Nahda and the Nidaa Tounes. The Nidaa Tounes is, in fact, a large coalition composed by secular, liberal, leftist groups, as well as ex-officials from Ben Ali's era. The majority of the electorate voted in favor of the Nidaa Tounes and al-Nahda both acquiring 86 and 69 seats respectively. In other words, al-Nahda had lost popularity compared to the 2011 election results but still represented a large segment of those who supported the Islamists.

Following the setting up of a Joint Committee for Cooperation and Drafting, which was responsible for coordinating the constitution-building process, the new constitution was inaugurated in 2014, not based on Islamic Shariah law but "dedicated to protecting citizens' rights, including protection from torture, the right to due process, and freedom of worship." ${ }^{21}$ The new election law also enshrined political participation and the establishment of various ideological groups. In addition, the new constitution also pledged equality for men and women before the law and protected the rights of women, which in fact represents a breakthrough with respect to freedom and gender equality in the entire MENA region.

However, the constitutional drafting process was not without concerns and heated debates. As Larbi Sadiki stated, "Democratic transition in Tunisia con- 
tinues to face challenges that are by no means intractable." ${ }^{22}$ The members of al-Nahda pointed out that there is no sufficient platform to articulate their ideas regarding the drafting process of new constitution. ${ }^{23}$ Specifically, the chief architect of the constitution was Habib Keder from al-Nahda, who chaired five of the six commissions of the drafting process. ${ }^{24}$

The constitution-building process has led the Tunisians to split over multiple disputant areas such as 'ideology' and Tunisian 'identity' that stretched back to the independence years as well as the issue of nation-building. ${ }^{25} \mathrm{Al}$-Nahda was eventually stuck between the conflicting ideas of Islamist and secular groups. On one side, the Islamists (primarily Salafi groups) rejects Tunisian Westernization; on the other side, the secularist coalition articulated their disapproval of the restrictions put forward over women's and civil rights by al-Nahda. ${ }^{26}$ For instance, within Nidaa Tounes, some of those affiliated with the Democratic Constitutional Rally (former President Ben Ali's ruling party) had experienced the radical Islamist era of al-Nahda -when they were excluded from the political arena during the 1980s- and had deep concerns regarding the new role of the party in Tunisian politics. ${ }^{27}$ This dichotomy between Islamists and secular movements has become endemic since the assassination of two figures of the opposition in 2013.

\section{The Tunisian Exception and the Role of Ghannouchi: 'Moderation through Exclusion'}

It has been widely argued that the democratic transition in Tunisia was neither Islamist nor secularist, which is consistent with the most successful cases in the MENA region since the Arab uprisings. The success of Tunisia was a direct result of the negotiation of compromise (tawafuk) between Islam and liberal democracy. In this regard, what makes al-Nahda a fundamentally different case from the Egyptian Ikhwan is primarily tied to the party's identity and agenda. During the 1970s and 1980s, al-Nahda transformed itself and acquired a national personality as a result of the sporadic inclusion of Islamist parties in the political system; it thereby became less Ikhwanized, unlike the Jordanian Brotherhood. For instance, the party emphasized 'Tunisian-ness' at its tenth congress. In his opening speech, Ghannouchi declared that al-Nahda's backing of national unity and compromise is not a 'safqa that al-tawila' (which means under-the-table deal). ${ }^{28}$ As put forward by Cavatorta and Merone, "The Tunisian case certainly reflects a type of exclusion against Ennahda ... however Ennahda went through to be able to find acceptance in the institutional game and, crucially, in wider society." ${ }^{29}$

Accordingly, Ghannouchi once also declared that "al-Nahda is a force for unity and togetherness, not for separation and division. We see Khaireddine al-Tunsi, Ahmed Bey, Moncef Bey, the late $z a^{\prime}$ im (leader) Habib Bourguiba, Farhat Hachad, Abdelaziz Thaalbi ... as symbols of our beloved nation." ${ }^{30}$ 
Thus, Ghannouchi "goes back to the values of the Koran rather than a literal reading of it ... [and] argues that these values - such as justice, public consultation, and human rights- are encapsulated in modern democratic states," as reported by the $B B C$ in $2012 .{ }^{31} \mathrm{He}$ also said that "The state should not have anything to do with imposing or telling people what to wear, what to eat and drink, what they believe in, what they should believe in."32

It was then agreed that the only reference to 'Islam' would be that stated in the 1957 Constitution of Tunisia, which reads: "Tunisia is a free, independent and sovereign state. Its religion is Islam, its language is Arabic, and its type of government is the Republic." ${ }^{33}$ It should be mentioned that the position of Ghannouchi was crucial at this stage. For instance, Slim Loghmani, a constitutional scholar, stated that the Tunisian constitution had begun to represent "a historic compromise between identity and modernity," which may build a mosaic of respecting human rights, good governance as well as Arab-Islamic heritage." ${ }^{34}$

In response to the trend of the Tunisian Islamist movement towards democratization, some also argued that al-Nahda was moving away from its agenda of political Islam through the separation of politics from religion and the shift away from the 'Islamist' label, instead mobilizing under the banner of 'Muslim democrats..$^{35} \mathrm{Al}$-Nahda was viewed as a viable alternative for Tunisians seeking good governance and a guarantee of both freedom and justice in the aftermath of the Arab protests. ${ }^{36}$ It had exhibited a capacity to compromise by forming a coalition government formed by three parties -embracing two center-leftist parties after the 2011 elections. This move also highlighted a long-standing debate on Islam: its compatibility with democracy. This way of understanding the role of Islam and Islamist actors in Western liberal-democracies is highly problematic. The case of al-Nahda also illustrated after the Arab riots that the traditional view of Orientalists, which sees Islam as the antithesis of liberal-democracy, is controversial given the acceptance of Islamist actors in the postArab upheavals era of universal liberal values and inclusionary attitudes. The emergence of the notion of post-Islamism since the 1990s is therefore helpful to understand the trajectory of Islamist actors since 2011 and is helpful in challenging the purported failure of Islamism.

Within this context, new features in Tunisian politics are identified in the fourth wave of the Arab Barometer, along with changing perspectives among Islamists in the eyes of the seculars. The results show that 86 percent of Tuni- 
sians today say that democracy, despite its problems, remains the best system of governance; this figure was 70 percent before the Jasmine Revolution in 2011. ${ }^{37}$

\section{Jordan's Spring: Reforms as Regime-Survival Strategy Instead of Democratic Transition}

Despite its diverse demographics and deeply rooted internal divisions, Jordan was not engulfed by the Arab rallies. What makes the Kingdom of Jordan distinct from other countries in the post-Arab spring era is intertwined with the kingdom's ability to consolidate its a monarchical rule, as well as the changing nature of Ikhwan-Jordanian monarchy relations.

Jordan represents a de facto bi-national society with the numerical majority of Jordanians with Palestinian origins in the country. In other words, the country is ethnically divided among East Bankers (native Jordanians) and West Bankers (Palestinian descent Jordanian citizens). Tribal loyalties epitomize another source of friction in Jordan, with Bedouins privileged as the primary source of legitimacy of the Hashemite monarchy. In Jordan, the internal divisions are also exacerbated by socio-economic differences along the same fault-lines. Although, Jordan's annexation of the West Bank territories in 1950, and King Abdullah I's policy of granting citizenship to Palestinian refugees means that the country is 'home' to a huge number of Palestinians. The uneven representation of the Palestinian descent Jordanians in the political arena since then has brought skepticism by Palestinians and led them to call for political reforms, i.e. the electoral law in particular. ${ }^{38}$ Thus, the Palestinian-Jordanian tension is also highly triggered by cross-cutting clashes, with Palestinian-Jordanians leading the economic realm and Jordanians dominating the political arena.

The Palestinian-Jordanian cleavage can clearly be detected in the political sphere, where Jordanians of Palestinian descent are affiliated with Ikhwan and its party, the Front. Jordan's political parties are not very strong, mainly due to political parties being banned for 35 years between 1957 and 1992. The IAF, which was formed in 1992 with the legalization of political parties, has come to represent the largest opposition group, having an organizational structure and an ideological platform.

After the influx of Iraqi refugees in 2003 across Jordan's borders, the Kingdom has recently witnessed a new socio-economic challenge with the entry of Syrian refugees from 2011 onwards. The flow of a considerable number of Syrian refugees with the onset of uprisings in neighboring country has resurfaced the persistent internal cleavages among the northern-urban vs. southern-rural areas as well. 
As far as the Arab uprisings are concerned, the case of Jordan must be analyzed differently from the case of Tunisia. At the outbreak of the Arab spring, protesters in Jordan were mainly calling for further political reform, as well as efforts to alleviate unemployment and corruption, rather than questioning the legitimacy of the monarchy itself. The Jordanian opposition organized the first huge march on January 2011, called 'The Day of Anger,' 39 and with

Public debate in Jordan has constantly centered on Jordanian demographics and political representation, addressing the limited and long-inadequate parliamentary representation of PalestinianJordanians in favor of Jordanian-Jordanians the growing public demand for political reform, the monarchy found itself in a difficult position. It responded by launching a series of constitutional reforms. Constitutional reforms are an 'old' tactic of the throne in times of internal unrest, but this regime survival strategy continues to effectively preserve the stability of the monarchy. ${ }^{40}$ The kingdom first employed 'return to democracy' as a survival strategy in 1989, following a public outcry that emerged in the southern city of Maan.

With the aim of containing the public protests, the regime established the $\mathrm{Na}$ tional Dialogue Committee (NDC), putting former ministers, opposition figures, and civil society organizations in charge of amending the laws around elections and political parties. ${ }^{41}$ The amendments also aimed to diminish the absolute powers of the king on critical issues like suspension of the parliament, keeping the government in office, re-appointing the prime minister and postponing elections until an unspecified date. ${ }^{42}$ As the head of the monarchy, King Abdullah II has the sole power to appoint the heads of the key institutional units, such as the Senate, military, police, and security forces as well as the constitutional court. The former Prime Minister and Defense Minister of Jordan, Faisal al-Fayez responded to the growing criticisms, saying, "A strong king means a strong Jordan." 43

Following the constitutional amendments implemented after 2011, the IAF, as the key opposition party described, the reform process as "leading to absolute rule and constituting a clear reversal from the reform discourse that the king had preached, especially with regard to the formation of parliamentary governments with full authority," with a statement issued on April 24, 2016. ${ }^{44}$ Similarly, Marwan Muasher -the former deputy Prime Minister, head of the Royal Committee for the National Agenda, and former Foreign Minister- said that the amendments "actually serve the king or ... enhance the principle of separation of powers." ${ }^{45}$ However, former Prime Minister Taher al-Masri described the amendments as paving the way for the formation of 


\section{The most significant outcomes of the Arab spring on Jordan was the war in Syria and the influx of a huge number of Syrian refugees into the country, which has been exacerbated by the diffusion of radical Jihadi groups across its borders}

As mentioned above, the Jordanian monarchy and the Muslim Brotherhood have traditionally built strong and non-confrontational ties. The Ikhwan in Jordan did not demonstrate its loyalty to the survival of the Kingdom, but it also acted as a safe haven between the opposition and the throne. One of the main sources of this close relationship was the Brotherhood's viable role as a deterrent to anti-regime forces -like Pan-Arab socialist, Nasserist and Ba'thist camps- and its tacit support for the kingdom's policy of unification of the West and East Banks throughout the 1950s and 1960s under King Hussein. It was precisely the fact of the regime's dependency upon Ikhwan during the heyday of Pan-Arabism and the Black September Episode (1970-1971) that allowed the Muslim Brotherhood to function as a charity organization and attract new members even before the ban on political parties.

Given this long-established strategic bond, it has been argued that Jordan's Islamist movement has a moderate and non-violent character that is distinct from those of its counterparts in the MENA region. Curtis C. Ryan describes the Islamist movement's position in Jordanian politics as "overwhelmingly reformist, rather than revolutionary, democratically-minded rather than militant," while noting, "nonetheless [there] remain alternative Islamist forces that focus on Jihadi ideas." 47

\section{Jordan's Quandary with Islam: Stability Comes First!}

Jordanians have seen six different prime ministers since the onset of the Arab upheavals. The Kingdom's main strategy during times of internal unrest has manifested in the reshuffling of governments; the second element of this strategy has traditionally been the redrafting of the electoral law. Jordan's electoral law thereby has been subjected to sporadic amendments, including in 1989, 1992, 2001, 2012, and 2015.

Jordan embarked on revising electoral law once again in 2015 before holding parliamentary elections in 2016. The motivation behind the amendment was to contain the opposition, particularly the IAF, due to its previous electoral boycotts of the 1997, 2010, and 2013 elections. The IAF's boycotts were motivated by the under-representation in electoral law of areas densely populated 


\section{In Tunisia, however, exclusion has after decades brought moderation, whilst after a long era of moderation and inclusion, the Jordanian Ikhwan finds itself on the edge of exclusion}

by Palestinian-descent Jordanians. Former Prime Minister Ensour labeled the newly revised election law of 2015 as "more or less the same as the always-praised 1989 law," which favored tribal candidates. More importantly, the IAF also described the revised law as a "step in the right direction" for the first time in Jordan's history. ${ }^{48}$

In the meantime, with ongoing instability in the region, Jordan has also been experiencing the spillover effects of the war in Syria. Although the UN says Jordan is hosting 635,000 of the 4.6 million Syrian refugees today, according to governmental sources, this number is greater than one million. King Abdullah II recently announced that "his country is at 'boiling point' because of an influx of hundreds of thousands of Syrian refugees." ${ }^{\text {" }}$ In an interview with the $B B C$, the king recently also said that "Jordanians were suffering as a result of the influx, with 25 percent of the state budget spent on helping refugees, public services under strain and many struggling to find jobs." ${ }^{\circ 0}$ The second impact of the war in Syria was the emergence of ISIS (the Islamic State in Iraq and Syria) as a non-state actor, which threatened the existing borders of the Middle East. The problem is not the Sharia character of ISIS but rather its territorial claim, which has the potential to affect the Middle East political map.

In summary, the most significant outcomes of the Arab spring on Jordan were the war in Syria and the influx of a huge number of Syrian refugees into the country, which has been exacerbated by the diffusion of radical Jihadi groups across its borders. Rather than concentrating on broadening political liberalization, the kingdom has taken new pre-emptive measures to contain dissenting groups and monitor radical groups. One of the consequences of this policy has been the kingdom's support of the newly established moderate wing within Ikhwan. The new group emerged immediately following a split within Ikhwan and is said to be linked to Gharaibeh's Zamzam Initiative -a coalition of moderate and reformist previous Brotherhood leaders- which was founded in $2012 . .^{51}$

\section{Ikhwan vis-à-vis the Monarchy: The Jordanianization of Ikhwan}

In 2015, a group of Islamists under the leadership of Jordanian origin, former leader of Jordan's Ikhwan, Abdul Majid Thuneybat, attempted to renew the movement's community statute license. After the overthrow of Ikhwan in Egypt in 2013, the Muslim Brotherhood was declared a terrorist organization by various countries such as Saudi Arabia and the United Arab Emirates 
(UAE). Jordan's Ikhwan leader Bani Irshid attacked the decision of the UAE in a Facebook post which culminated in a trial under the Anti-Terrorism Law for "disrupting relations with a foreign state." ${ }^{52}$ Jordan's 'new' Ikhwan attempted to secure its registry by distancing itself from Egypt's Ikhwan, which led to a questioning of the status of the 'old' Ikhwan. The Prime Minister at the time, Abdullah Ensour, also took sides in the debate, saying, "Ikhwan in Jordan is illegal. It does not have a license of community statute and has missed the right of legitimacy." ${ }^{33}$ Abdul Majid Thuneybat has insisted that his objective was to sever ties with "the terrorist group in Egypt" and renew the license of Ikhwan. The old Ikhwan pointed out, however, that "without such licensing, it would not have managed to participate in Jordan's social and political life for almost 70 years." 54

According to Orieb al-Rantawi, the head of the Center of al-Kudus al-Arabi in Amman, the prevailing tension between the old and new Ikhwan extends from an internal divide over 'priorities and identities.' Al-Rantawi recently told Al-Monitor, "What the media does not tell you is that the power struggle is between two distinct groups [Jordanians and Jordanians of Palestinian origin], and the government has taken sides, although the new society has no grass-roots support." 55 The main objective of the new group within the Brotherhood was to differentiate itself from the conservative wing -the hawks. On November 4, 2015, the new group announced it would join a party to be formed by the Zamzam Initiative under the leadership of Irhail al-Gharaibeh.

Thus, the longstanding close relationship between Ikhwan and the monarchy did not historically allow secular or leftist parties to form a coalition to oppose the kingdom's policies. As mentioned above, the lack of an ideological or a mass party, as well as the weakness of the political actors' ideological grounds, help the IAF to act as the key opposition actor in Jordanian politics. ${ }^{56}$ However, the split within the Brotherhood and the regime's changing perceptions towards the movement has meant that the long-standing and non-confrontational nature of relations between them have been replaced by fragility and mistrust over the last decade.

\section{Incoherence among Islamist Parties after the Arab Uprisings}

Jillian Schwedler argued that most Islamist movements that function as integral parts of political systems are not actually radical. ${ }^{57}$ Her approach on the inclusion-moderation hypothesis "is that inclusion may deflate radicalism and turn revolutionaries into reformers, not that moderates may become more moderate." ${ }^{58}$ In Tunisia, however, exclusion has after decades brought moderation, whilst after a long era of moderation and inclusion, the Jor- 
danian Ikhwan finds itself on the edge of exclusion. The main aim of this article is to highlight how divergent Islamist parties' trajectories have been in the post-Arab uprisings era by exploring two specific cases with reference to their particular national and regional contexts, and the degree to which each has embraced democratization. So, this work may also shed light on the question of whether there is a correlation between the inclusion of Islamist actors and their political moderation, as well as in the trend towards democratization.

At first sight, what makes the case of Jordan different from that of Tunisia is unequivocally the role of religion during the processes of nation and state building. Islam has historically been an integral part of Jordanian internal and foreign policy with regard to East Jerusalem and the West Bank and has also been a major source of the regime's legitimacy. Accordingly, Gudrun Kramer pointed to the connection between the king's descent from the Prophet Mohammad's lineage and his legitimacy among much of the populous, noting that the case of "Jordan offers a more complex set-up, in which Islamic activism and communal loyalties (referring to the Palestinians in particular) are to a certain extent connected or interrelated." ${ }^{9}$

Secondly, the public protests in Jordan did not directly target the Hashemite monarchy, which depicts a clear discrepancy between the two countries. Unlike the case of Tunisia, the Jordanian public never called for regime change or for the overthrow of the monarchy. Instead, the protesters called for more economic and political reforms; the unrest remained mainly economically driven and democratization efforts did not, in fact, move forward. The Tunisian experience was quite different: the Arab uprisings have reinforced a deep transition towards regime change, as well as democratization, which can be corroborated in reports by Freedom House. Tunisia had been evaluated among "not free" countries until the 2011 Arab uprisings; by 2017 its evaluation had been upgraded to "free" with 2 points out $7 .{ }^{60}$ Its press freedom is also rated as "partly free," as compared to the "not free" rating of many countries in the region. In contrast, for the case of Jordan, the Freedom House reports show that the country is described as "partly free" with 5 points out of 7 and its press freedom score is "not free." ${ }^{\text {"T }}$ The post-2011 uprisings period has demonstrated that the public protests have culminated in neither democratic transitions (with the exception of Tunisia) nor structural reconfiguration of authoritarian rules in the MENA region. Although the uprisings alarmed and led to the toppling of some of the incumbent rulers; the durability and resilience of authoritarianism has remained persistent in most parts of the region.

The republics, contrary to Arab monarchies like Jordan and Morocco, were vastly shaken by large-scale demonstrations despite the pre-emptive mea- 
sures of co-optation of the opposition enforced during their longtime rule. As characterized by Raymond Hinnebusch, the regimes in the region consolidated their rule through "authoritarian upgrading" 62 and "authoritarian resilience," whereby "regimes appear to have given themselves liberal democratic forms while remaining autocratic in substance, halting what was expected to be an inevitable slide away from an ever-precarious autocracy towards democracy." ${ }^{63}$ Egypt, Jordan, and Tunisia are the best examples of this regime type having regular elections (with periodic intervals), multiparty politics (after 1976 in Egypt, after 1992 in Jordan) and independent judiciaries. However, the real power is not vested in the hands of the elected legislature.

Within this context, the Arab uprisings, in one case, prompted political reforms that have led to an era of 'democratic transition' that includes an opening

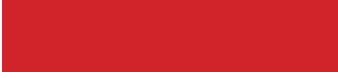

In the case of Jordan, the spillover effect of the war in Syria and the prolonged, internally driven crosscutting cleavages have historically muddled processes of democratization and the regime's ties with the Ikhwan for Islamist actors. In another case, one in which the Ikhwan and the Islamists were already involved in and encapsulated by the trend towards democratization, the uprisings constituted another setback that provoked a regime-survival strategy. Thus, Tunisia and Jordan constitute two divergent cases in the post-Arab spring era that nevertheless have both led towards democratization, as well as the inclusion of Islamist actors through moderation. In other words, this paper has explored the changing natures and roles of al-Nahda in Tunisia and the Muslim Brotherhood in Jordan with reference to context-dependent dynamics and external challenges. Thus, to understand Islamist parties in the post-2011 era, varying trajectories of state-formation and the degree of democratization really does matter.

Hence, the insurgence of al-Qaeda-affiliated groups like ISIS and al-Nusra, and the possible spillover effects of the situation in Iraq and Syria illustrate that the Kingdom of Jordan is not immune to the turmoil and transition happening throughout the region by virtue of its geographical and geopolitical location - particularly compared with Tunisia, which is located in the Maghreb. Since the outbreak of the uprisings in Syria, the Kingdom has refrained from meddling in the internal affairs of its neighbor, pursuing only a limited, humanitarian role by providing shelter to refugees, more than 75 percent of whom are women and children. ${ }^{64}$

As a party to the Palestinian-Israeli conflict, Jordan has always needed to balance its foreign policy against the effects of external actors. Within this context, 


\section{The spillover effects of the conflict in Syria, the instability in Libya, and the overthrow of Ikhwan in Egypt have inhibited al-Nahda from pursuing its bargaining power over critical issues vis-à-vis the Nidaa Tounes}

the territorial integrity of Syria and Iraq, as well as the stability of the Middle East, are the Kingdom's top priorities. Since 2011, Jordan has attempted to undertake a pre-emptive strategy to monitor the growing opposition and to contain the insurgence of Islamist actors inside the country -precisely the Salafis and Jihadi Islamists. The greatest challenge to the regime's ties with its Islamist movement, Ikhwan, has been this growing danger posed by Jihadi Islamists across its borders and the overthrow of Egypt's Ikhwan in 2013. The November 2005 terrorist attacks - described as Jordan's 9/11- alerted the kingdom to the growing influence of radical Islamists. Abu Mohammed al-Maqdisi who is one of the key figures of the Salafi movement in Jordan (and also mentor of Abu Mussab al-Zarqawi who was leader of al-Qaeda in Iraq and claimed responsibility for the Amman bombings in 2005) was put on trial in a military court on charges of terrorism and recruiting people to join al-Qaeda. Maqdisi was influential "in condemning ISIS' ideology and methods following its emergence in Syria and Iraq." 65

The Salafists also demonstrated to demand the release of 90 Islamist prisoners, including Maqdisi. BBC World indicates that "Their demonstrations [in April 2011] are separate from the 14-week-old wave of anti-government protests by leftists and more moderate Islamists, who are demanding democratic reforms in the kingdom." 66 This also illustrates that the public protests in Jordan should be considered separately from these Salafi Islamists' rallies in the wake of the Arab Spring since the majority of protests were run by Jordanian-Jordanians (of East Bank origin) of various societal segments, without the direct involvement of the Islamists and the Ikhwan.

In Jordan as elsewhere, Salafi Islamists are demanding the implementation of Islamic Sharia law; in other words, they want to establish an Islamic state in Jordan. Despite their generally low profile within the kingdom, Jordanian Salafi Islamists are actively involved in fighting against Bashar Assad's rule in Syria, and some have been "convicted of trying to recruit people to fight against U.S.-led troops in Iraq and Afghanistan, plotting attacks against U.S. and Israeli embassies in Amman, or planning to kill foreign tourists." ${ }^{7}$ For 

In the case of Tunisia, the exclusion of Islamists has reinforced their moderation, but in Jordan the long era of moderation has come to an end, and Islamists have begun to be seen as the primary threat to the monarchy
Jordan during the post-2011 era has been stagnant.

Tunisia has yet proximity to Libya and is also under the influence of and at risk from ISIS militants, where "some of the thousands of Tunisian foreign fighters could return and exploit simmering social unrest;" "72 still, the main source of instability is internal rather than externally driven, unlike the case of Jordan. Since the formation of the government coalition led by two of the country's key political parties -i.e. Nidaa Tounes and al-Nahda-

Tunisia has been engaged in an ideological polarization process: as "former enemies turned partners, they are struggling to conserve their political identity and internal cohesion; conflicts surface in line with the strengthening or weakening of their respective powers of negotiation within the partnership."73 Despite their rivalries, the two political camps have also shown a willingness to collaborate; on "several occasions, Ghannouchi supported the draft law of the president of the republic on economic and financial reconciliation, despite vivid criticism against the bill."? ${ }^{74}$

It should be stated that the spillover effects of the conflict in Syria, the instability in Libya, and the overthrow of Ikhwan in Egypt have inhibited al-Nahda from pursuing its bargaining power over critical issues vis-à-vis the Nidaa Tounes. ${ }^{75}$ Regional unsteadiness has in some way precluded al-Nahda from pursuing a proactive role in domestic affairs, but this does not suggest that it will not opt for a compromise.

Furthermore, unlike in Jordan, the main source of public debates in Tunisia has centered on ideological clashes instead of national or tribal tensions. Tunisia has a longer tradition of political parties and mobilization than the Kingdom of Jordan, where political parties were banned between 1957 and 1992. For that reason, as an Arab republic, Tunisia had been engaged in party politics and pluralism primarily during the heyday of Arabism and Nasserism. Rather than mobilizing tribalism and attachment to the King's Islamist credentials, Tunisian state-formation revolved around gaining popular support through secular Arab nationalist, leftist, and other ideological camps, something Jordan was absolutely deprived of. It is due to this fact that Post-Islamism was called into question because the role of al-Nahda was influential in recruiting and attracting new members in the days after the public rallies. However, the position of Jordan's Ikhwan was more precarious in the early days of the riots for not being treated again as a 'threat' from the beginning. 


\section{Concluding Remarks}

This article has aimed to illustrate that there is no coherence in the Arab Middle East as far as the nature of Islamist political parties and the way they have been treated by the regimes since the Arab uprisings. In other words, the uprisings have served to highlight the variety of political systems and regime types around the Arab world. ${ }^{76}$ Within this framework, this work has been an attempt to scrutinize the validity of Islamism and its different trajectories, as well as how each national context produces its own forms of Islamist politics.

Since the onset of the Arab spring, it has been argued that Islamists would come to power around the region with a drastic increase in political openings. In the case of Tunisia, after an era of exclusion al-Nahda has come to play a crucial role in the process of democratization, "having committed its considerable resources to the construction of a new plural democratic political system that would respect civil liberties and human rights." ${ }^{77}$ In contrast to the Post-Islamism argument, for Ghannouchi, "Tunisia is now an Islamic state because it guarantees liberty and justice -the fundamental social goals of Islam- might therefore not be a simple rhetorical device to convince a constituency that feels the party has abandoned the genuine striving for the creation of an Islamic state."78

In stark contrast, the Islamist movement in Jordan -which had established a non-confrontational relationship with the kingdom rarely seen in the MENA region- has begun to be seen as a potential threat to the monarchy and is monitored by the regime in the post-Arab spring era. Recent developments have revealed that the more steps the Jordanian monarchy takes towards democratization, the less Islamists are moderated -including in the political sphere. Yet, the recent quest for the Jordanianization of the Brotherhood displays a change in the regime's perception of Islamists in the wake of regional turmoil and the insurgence of radical Islamist movements across its borders. Thus, compromise in the Tunisian example was achieved among the political actors, which has enabled Tunisians to produce cross-cutting ideological coalitions including al-Nahda. Meanwhile, the case of Jordan shows that it is the monarchy itself that the Ikhwan has to negotiate with, rather than attempting to bargain with a political party.

The variations in trajectories of state and nation formation, as well as the regional dynamics shaping domestic politics and internal cleavages in both Tunisia and Jordan, are evidence that the Arab states around the MENA region are not monolithic. One of the upshots of the Arab uprisings is, therefore, the manifestation of incoherence among the countries in the region. In the case of Tunisia, the exclusion of Islamists (Ghannouchi and al-Nahda) has 
reinforced their moderation, but in Jordan, the long era of moderation has come to an end, and Islamists have begun to be seen as the primary threat to the monarchy.

\section{Endnotes}

1. John Bradley, After the Arab Spring: How Islamists Hijacked the Middle East Revolts, (MacMillan: Palgrave, 2012).

2. Mansoor Moaddel, Jordanian Exceptionalism: A Comparative Analysis of Religion and State Relationships in Egypt, Iran, Jordan, and Syria, (New York: Palgrave, 2002).

3. Marc Lynch, "Obama's Arab Spring," Foreign Policy, (January 6, 2011), retrieved from https://foreignpolicy.com/2011/01/06/obamas-arab-spring/.

4. Tarek Chamkhi, "Neo-Islamism in the post-Arab Spring," Contemporary Politics, Vol. 20, No. 4 (2014), p. 453.

5. Bradley, After the Arab Spring.

6. Katerina Dalacoura, "The 2011 Uprisings in the Arab Middle East: Political Change and Geopolitical Implications," International Affairs, Vol. 88, No. 1 (2012), p. 74.

7. Markus Holdo, "Post-Islamism and Fields of Contention after the Arab Spring: Feminism, Salafism and the Revolutionary Youth," Third World Quarterly, Vol. 38, No. 8 (2017), p. 1.

8. Holdo, "Post-Islamism and Fields of Contention after the Arab Spring."

9. Asaf Bayat, "The Coming of a Post-Islamist Society, Critique," Critical Middle Eastern Studies, Vol. 5, No. 9 (1996), pp. 45-46.

10. Asef Bayat, "Islamists Aren't Coming!" Insight Turkey, Vol. 13, No. 2 (2011), p. 14. Emphasis added.

11. Francesco Cavatorta and Fabio Merone, "Post-Islamism, Ideological Evolution and 'la Tunisianité' of the Tunisian Islamist Party al-Nahda," Journal of Political Ideologies, Vol. 20, No. 1 (2015).

12. Cavatorta and Merone, "Post-Islamism, Ideological Evolution and 'la Tunisianité' of the Tunisian Islamist Party al-Nahda," p. 38.

13. Cavatorta and Merone, "Post-Islamism, Ideological Evolution and 'la Tunisianité' of the Tunisian Islamist Party al-Nahda."

14. Khalil al-Anani, "Islamist Parties Post-Arab Spring," Mediterranean Politics, Vol. 17, No. 3 (2012), p. 466.

15. Nur Köprülü, "Islamist Actors after the 2011 Arab Uprisings," Turkish Policy Quarterly, Vol. 16, No. 3 (2017).

16. Robin Wright (ed.), The Islamists Are Coming: Who They Really Are, (Washington D.C.: Woodrow Wilson Center Press, 2012).

17. Chamkhi, "Neo-Islamism in the post-Arab Spring," p. 458.

18. "Tunisia Signs New Constitution," The Guardian, (January 27, 2014), retrieved February 22, 2018, from https://www.theguardian.com/world/2014/jan/27/tunisia-signs-new-constitution-progressive.

19. Raymond Hinnebusch, "Toward a Historical Sociology of State Formation in the Middle East," Middle East Critique, Vol. 19, No. 3 (2010), pp. 208-209.

20. Francesco Cavatorta and Fabio Merone, "Moderation through Exclusion? The Journey of the Tunisian Ennahda from Fundamentalist to Conservative Party," Democratization, Vol. 20, No. 5 (2013), p. 870.

21. Cavatorta and Merone, "Moderation through Exclusion?"

22. Larbi Sadiki, "Tunisia's Constitution: A Success Story?" Al Jazeera, (January 27, 2014), retrieved from https://www.aljazeera.com/indepth/opinion/2014/01/tunisia-constitution-success-s-2014121122929 203231.html. 
23. "Tunisia, Political Participation and Ideological Compromise," Mediterranean Affairs, (February 22, 2016), retrieved from http://mediterraneanaffairs.com/tunisia-political-participation-and-ideologicalcompromise/.

24. Duncan Pickard, "The Current Status of Constitution Making in Tunisia," Carnegie Endowment for International Peace, (April 19, 2012), retrieved June 7, 2015, from https://carnegieendowment. org/2012/04/19/current-status-of-constitution-making-in-tunisia-pub-47908.

25. "Tunisia, Political Participation and Ideological Compromise."

26. "Tunisia, Political Participation and Ideological Compromise."

27. "Stemming Tunisia's Authoritarian Drift," International Crisis Group, (January 11, 2018), retrieved from https://d2071andvip0wj.cloudfront.net/180-stemming-tunisias-authoritarian-drift_0.pdf, p. 2.

28. Monica Marks, "A Response to Sayida Ounissi's' Ennahda from within: Islamists or 'Muslim Democrats'?"' Brookings, (June 2016), retrieved from https://www.brookings.edu/wp-content/uploads/2016/ 07/MonicaMarks_re2SayidaOunissi2.pdf.

29. Cavatorta and Merone, "Moderation through Exclusion?" p. 859.

30. Cavatorta and Merone, "Moderation through Exclusion?"

31. Mukul Devichand, "Rashid Ghannouchi on Britain, Islam and Liberal Democracy," BBC, (February 12, 2012), retrieved from http://www.bbc.com/news/world-16932923.

32. Devichand, "Rashid Ghannouchi on Britain, Islam and Liberal Democracy."

33. Pickard, "The Current Status of Constitution Making in Tunisia."

34. "Tunisia Signs New Constitution."

35. "Stemming Tunisia's Authoritarian Drift," International Crisis Group.

36. Monica Marks and Sayida Ounissi, "Ennahda from within: Islamists or "Muslim Democrats"? A Conversation," Brookings, (March 23, 2016), retrieved from https://www.brookings.edu/research/ennahdafrom-within-islamists-or-muslim-democrats-a-conversation/.

37. Michael Robbins, "Tunisia Five Years after the Revolution," Arab Barometer, (May 15, 2016), retrieved from http://www.arabbarometer.org/wp-content/uploads/Tunisia_Public_Opinion_Survey_2016_Democracy.pdf.

38. This 'East Bank-West Bank' division is, in essence, a division between Jordanian citizens of Palestinian origin and Jordanian-Jordanians.

39. Curtis R. Ryan, "Five Years after Arab Uprisings, Security Trumps Reforms in Jordan," The Washington Post, (March 4, 2016), retrieved from https://www.washingtonpost.com/news/monkey-cage/wp/2016/ 03/04/five-years-after-arab-uprisings-security-trumps-reforms-in-jordan/?utm_term=.7a2c25e483f1.

40. Nur Köprülü, "Consolidated Monarchies in the 'Post-Arab Spring' Era: The Case of Jordan," Israel Affairs, Vol. 20, No. 3 (2014).

41. "Popular Reform in North Africa and the Middle East (IX): Dallying with Reform in a Divided Jordan," International Crisis Group, Report No. 118, (2012), p. 3, retrieved from https://www.crisisgroup.org/ middle-east-north-africa/eastern-mediterranean/jordan/popular-protest-north-africa-and-middleeast-ix-dallying-reform-divided-jordan.

42. Osama al-Sharif, "Changes to Jordan's Constitution Raise Concerns," Al-Monitor, (May 4, 2016), retrieved from http://www.al-monitor.com/pulse/originals/2016/05/jordan-adopts-constitution-amendments-king-powers.html\#ixzz4kSrdh4xO.

43. Al-Sharif "Changes in Jordanian Constitution Raise Concerns."

44. "King Abdullah Dissolves Jordan's Parliament amid Fears of Absolute Monarchy," Alwaght, (May 29, 2016), retrieved from http://alwaght.com/en/News/54869/King-Abdullah-Dissolves-Jordan\%E2\%80\% 99s-Parliament-amid-Fears-of-Absolute-Monarchy.

45. Marwan Muasher, "Jordan's Proposed Constitutional Amendments: A First Step in the Right Direction," Carnegie Endowment for International Peace, (August 17, 2011), retrieved from https://carnegieen- 
dowment.org/2011/08/17/jordan-s-proposed-constitutional-amendments-first-step-in-right-direction-pub-45366.

46. Hassan A. Barari, "The Limits of Political Reform in Jordan," Friedrich Ebert Stiftung, (December 2013), retrieved from http://library.fes.de/pdf-files/iez/10455-20140108.pdf.

47. Curtis C. Ryan, "Islamist Political Activism in Jordan: Moderation, Militancy, and Democracy," Scholars for Peace in the Middle East Reports, Vol. 12, No. 2 (2008), retrieved February 14, 2010, from https://spme. org/boycotts-divestments-sanctions-bds/boycotts-divestments-and-sanctions-bds-news/curtis-cryan-islamist-political-activism-in-jordan-moderation-militancy-and-democracy/5146/.

48. Raed Omari, "New Elections Bill Sheds One-Vote System," The Jordan Times, (August 31, 2015), retrieved from http://www.jordantimes.com/news/local/new-elections-bill-sheds-one-vote-system.

49. "Syria Conflict: Jordanians 'at Boiling Point' over Refugees," $B B C$, (February 2, 2016), retrieved from http://www.bbc.com/news/world-middle-east-35462698.

50. "Syria Conflict: Jordanians 'at Boiling Point' over Refugees."

51. Aida Alami, "Rift Deepens within Jordan's Muslim Brotherhood," Al Jazeera, (August 17, 2015), retrieved from http://www.aljazeera.com/news/2015/08/rift-deepens-jordan-muslim-brotherhood-150 810121308733.html.

52. "Jordan Pressured to Restrict Muslim Brotherhood," Al-Monitor, (February 3, 2015), retrieved from http://www.al-monitor.com/pulse/originals/2015/02/jordan-muslim-brotherhood-gulf-aid.html\#ixzz3wrFTkznY.

53. "Ürdün'de İhvan’ın Meşruiyeti Tartışılıyor," TRT Haber, (July 6, 2015), retrieved from http://www. trthaber.com/haber/dunya/urdunde-ihvanin-mesruiyeti-tartisiliyor-192989.html.

54. Osama al-Sharif, "Jordan Takes Sides in Islamist Rift," Al-Monitor, (May 12, 2015), retrieved from http:// www.al-monitor.com/pulse/originals/2015/05/jordan-government-side-muslim-brotherhood-society-split.html\#ixzz3wrKZfX3b.

55. Al-Sharif, "Jordan Takes Sides in Islamist Rift."

56. Nur Köprülü, "Islamist Actors after the 2011 Arab Uprisings."

57. Nur Köprülü, "Jordan since the Uprisings: Between Change and Stability," Middle East Policy, Vol. 21, No. 2 (2014), p. 116.

58. Jillian Schwedler, Faith in Moderation: Islamist Parties in Jordan and Yemen, (Cambridge: Cambridge University Press, 2006).

59. Gudrun Kramer, "The Integration of the Integrists: A Comparative Study of Egypt, Jordan and Tunisia," in Ghassan Salame (ed.), Democracy Without Democrats, (London: I. B. Tauris, 1994), p. 219.

60. Freedom House scale: $1=$ Most Free, $7=$ Least Free. Tunisia profile is retrieved from https://freedomhouse.org/report/freedom-world/2017/tunisia.

61. Jordan profile is retrieved from https://freedomhouse.org/report/freedom-world/2017/jordan.

62. Raymond Hinnebusch, "Authoritarian Resilience and Arab Uprising: Syria in Comparative Perspective," Ortadoğu Etüdleri, Vol. 7, No. 1 (2015), p. 18.

63. Steven Heydemann and Reinoud Leenders, "Authoritarian Learning and Authoritarian Resilience: Regime Responses to the 'Arab Awakening," Globalization, Vol. 8, No. 5 (2011).

64. Richard A. Kauffman, "Syrian Refugee Crisis Hits Neighbouring Countries," Christian Century, Vol. 130, No. 8 (April 17, 2013), p. 18.

65. Osama al-Sharif, "Jordan and the Challenge of Salafi Jihadis," Middle East Institute, (March 21, 2016), retrieved from https://www.mei.edu/publications/jordan-and-challenge-salafi-jihadists.

66. "Jordan Unrest: Salafist Clash Wounds Dozens in Zarqa," BBC, (April 15, 2011), retrieved from http:// www.bbc.com/news/world-middle-east-13097059.

67. Dale Gavlak, "Jordan Protests: Rise of the Salafist Jihadist Movement," BBC, (April 22, 2011), retrieved from http://www.bbc.co.uk/news/world-middle-east-13163870. 
68. Suha Philip Ma'ayeh, "Jordanian Jihadists Active in Syria," Combating Terrorism Center, (October 24, 2013), retrieved from https://ctc.usma.edu/jordanian-jihadists-active-in-syria/.

69. Ma'ayeh, "Jordanian Jihadists Active in Syria."

70. This statistic is retrieved from https://www.statista.com/statistics/385565/unemployment-rate-injordan/.

71. Curtis R. Ryan, "Deja vu for Jordanian Election Reforms," The Washington Post, (September 2, 2015), retrieved from https://www.washingtonpost.com/news/monkey-cage/wp/2015/09/02/deja-vu-for-jordanian-election-reforms/?utm_term=.a7db2bd526b2.

72. "Tunisia's Political Polarisation Worsens after First Big Terrorist Attack in Two Years," International Crisis Group, (October 30, 2018), retrieved from https://www.crisisgroup.org/middle-east-north-africa/ north-africa/tunisia/tunisias-political-polarisation-worsens-after-first-big-terrorist-attack-two-years.

73. Middle East and North Africa Report No. 180, "Stemming Tunisia's Authoritarian Drift."

74. Middle East and North Africa Report No. 180, "Stemming Tunisia's Authoritarian Drift."

75. Middle East and North Africa Report No. 180, "Stemming Tunisia's Authoritarian Drift."

76. Dalacoura, "The 2011 Uprisings in the Arab Middle East: Political Change and Geopolitical Implications."

77. Cavatorta and Merone, "Moderation through Exclusion?" p. 859.

78. Cavatorta and Merone, "Post-Islamism, Ideological Evolution and 'la Tunisianité' of the Tunisian Islamist Party al-Nahda," p. 40. 


\section{SETA}

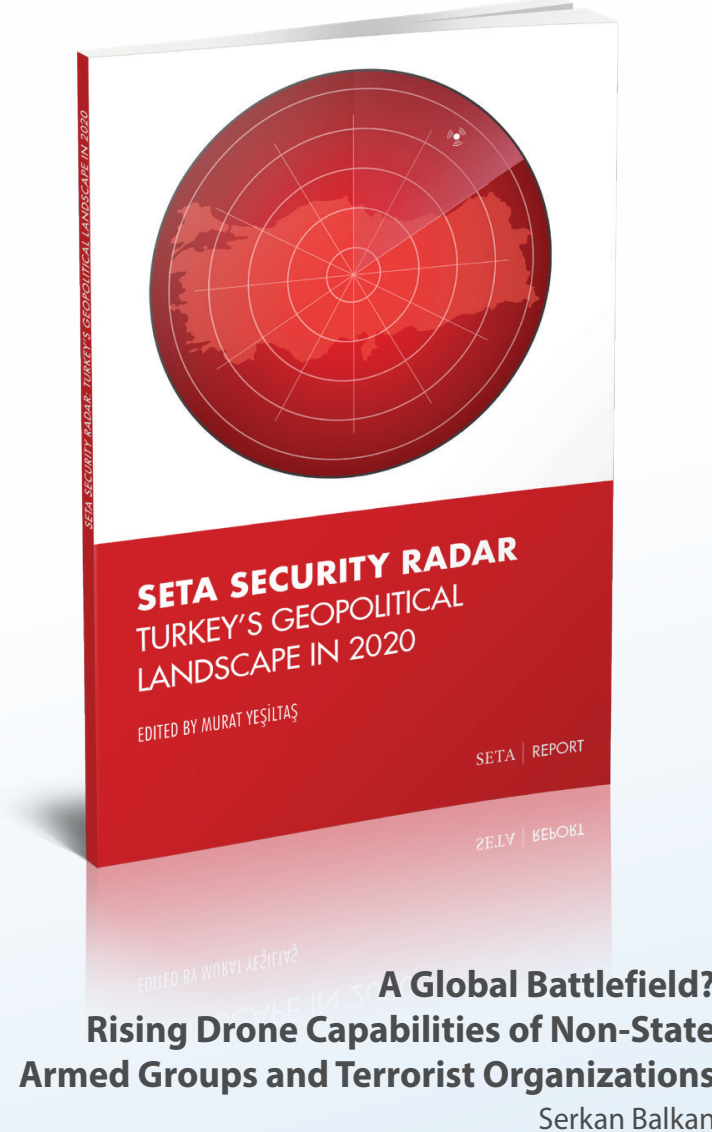

SETA Security Radar |

Turkey's Security Landscape in $\mathbf{2 0 2 0}$

Murat Yeşiltaş, Murat Aslan, Bilgehan Öztürk,

Rıfat Öncel, Ümit Tetik, Ömer Özkizilcik,

Sibel Düz, Nur Günay

SETA Security Radar attempts to anticipate the course of major security issues Turkey faces and how to develop and enhance sound and relevant responses within this increasingly challenging regional security environment.

This study examines how terrorist organizations use UAV technology by learning from each other and analyzes their adaptation processes.
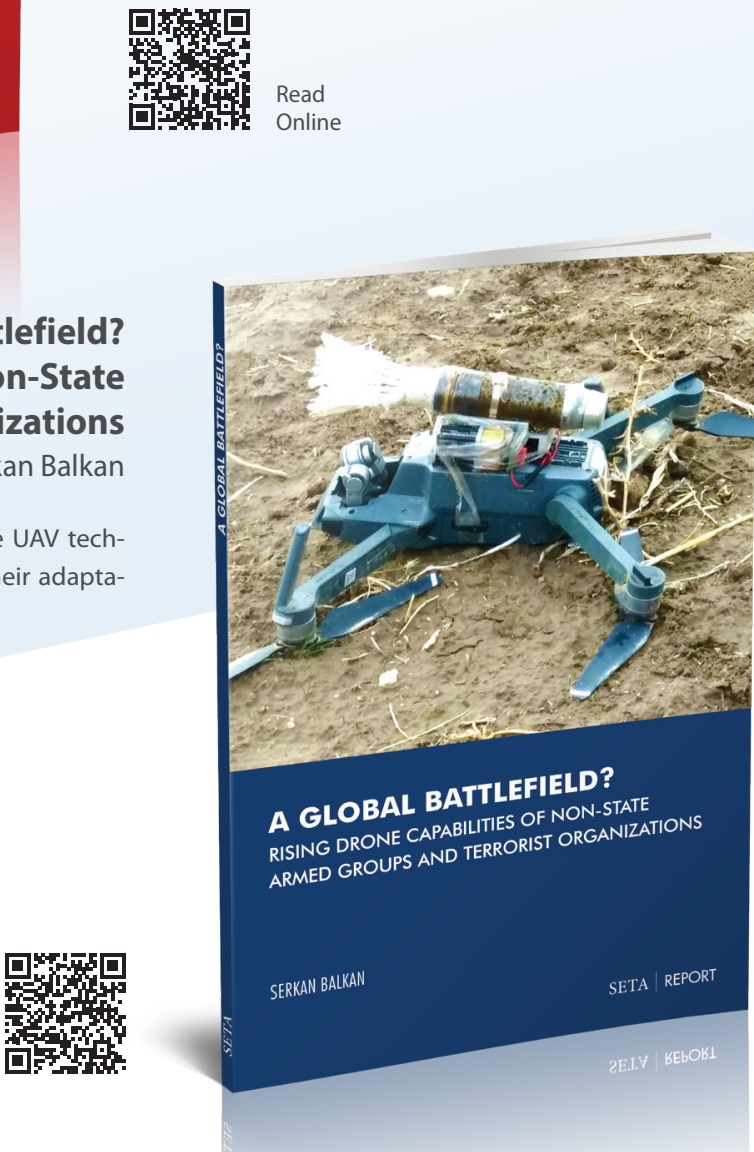